\title{
Purulent infection in the third finger with associated osteomyelitis
}

\author{
Ivan Couto-Gonzalez, Beatriz Brea-García, Antonio Taboada-Suárez
}

Department of Plastic and Reconstructive Surgery, Complejo Hospitalario Universitario de Santiago de Compostela, Santiago de Compostela, A Coruña, Spain

\section{Correspondence to} Dr Ivan Couto-Gonzalez, ivan_couto@hotmail.com
To cite: Couto-Gonzalez I, Brea-García B, TaboadaSuárez A. BMJ Case Rep Published online: [please include Day Month Year] doi:10.1136/bcr-2012008476

\section{DESCRIPTION}

An 82-year-old woman was referred to our department due to swelling, warmth and severe functional impairment in the third finger of her right hand. She had a medical history of arterial hypertension, diabetes mellitus and atrial fibrillation. After physical examination, severe tumefaction of the finger was evident (figure 1). Spontaneous flexion of the distal interphalangeal joint with full incompetence to active extension and severe pain upon passive extension were noted. Pain was experienced with flexo-extension movements in the proximal interphalangeal joint and increased when the volar aspect of the finger was pressed above the flexor tendon sheath. The patient reported an accidental prick with a needle in the volar aspect of the distal phalanx (DP) almost 2 months ago. Inflammation and purulent exudate occurred over the following 2 weeks but the patient did not seek medical counsel.

The patient's temperature was $36.3^{\circ} \mathrm{C}$ and blood analysis revealed mild leucocytosis (12 500 cells/dl). Plain radiography of the affected finger showed a type-IV osteomyelitis with full-thickness bone sequestrum of the DP and the distal third of the middle phalanx (MP; figure 2). Complete
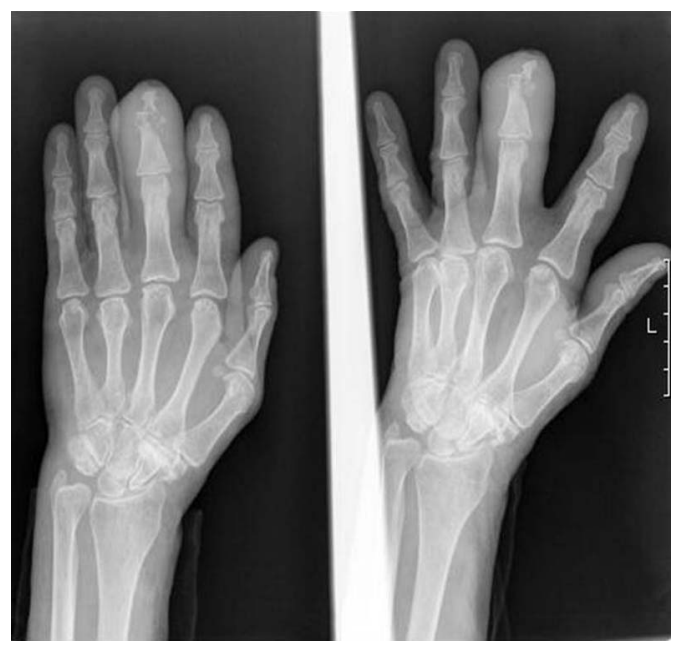

Figure 2 Plain radiographies of the affected hand. Full-thickness bone sequestrum of the distal phalanx, distal interphalangeal joint and distal half of the middle phalanx is observed.

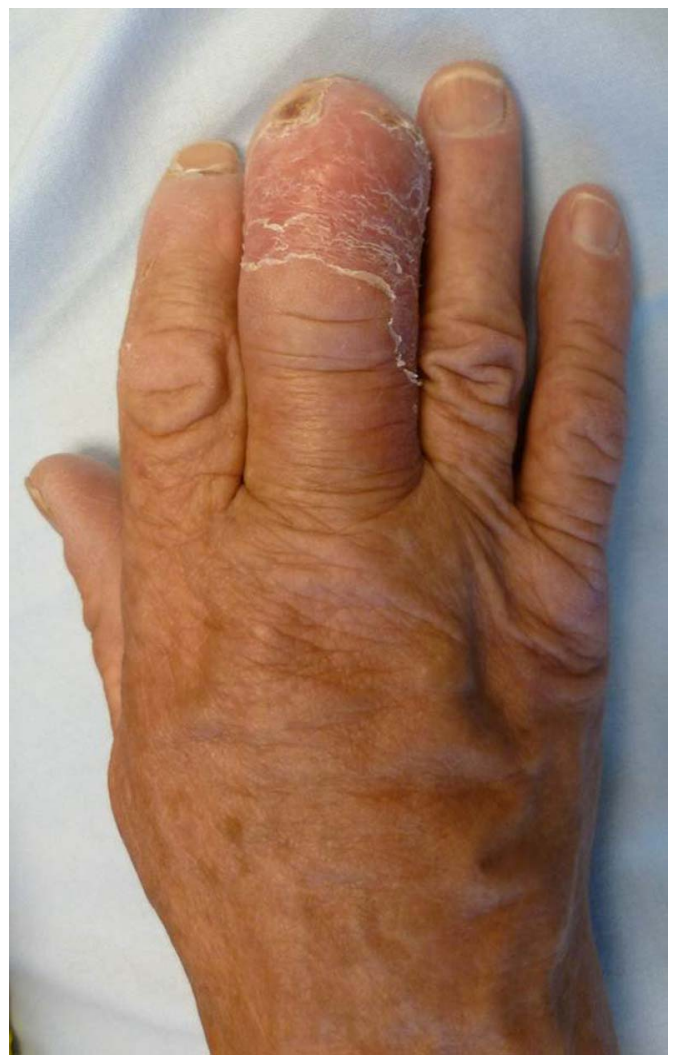

Figure 1 View of the dorsal aspect of the third finger at physical examination. Note the enlargement of the finger and the passive flexion of the distal interphalangeal joint.

destruction and instability of the distal interphalangeal joint was observed.

A drainage incision was performed along the radial neutral line and spontaneous purulent oozing from the volar aspects of the DP and MP occurred. The soft tissues in the dorsal aspect of theses phalanxes and even the extensor tendon showed necrosis.

The patient underwent amputation of the DP and the distal half of the MP. Multiple surgical debridements were carried out over the following days before the wound was definitively closed. Upon hospitalisation, the patient received endovenous antibiotic treatment with clindamycin $(600 \mathrm{mg}$ every $8 \mathrm{~h}$ ) and gentamicin (240 mg every $24 \mathrm{~h}$ ) for 10 days until the patient was discharged. 


\section{Learning points}

- Osteomyelitis in the fingers, although infrequent, is usually related to surrounding soft tissue infections, especially after a penetrating trauma. ${ }^{1}$

- Patients with vascular disease or immunodeficiency have an increased risk of developing osteomyelitis. Other contributing factors could be contamination and severe damage in the soft tissues when injury occurs. ${ }^{2}$

- Radiographic findings are extremely infrequent in acute osteomyelitis (excluding soft tissue swelling). The first radiological signs in the bone usually appear 10-14 days after the onset of the infection. ${ }^{3}$

- In acute or chronic osteomyelitis, the optimal duration of antibiotic therapy remains unclear although 6 weeks is the most frequent regimen. ${ }^{4}$ Amputation of the involved finger or extremity may reduce the time of the antibiotic therapy if the remaining soft tissues and bone are free of disease.
Competing interests None.

Patient consent Obtained.

Provenance and peer review Not commissioned; externally peer reviewed.

\section{REFERENCES}

1 Reilly KE, Linz JC, Stern PJ, et al. Osteomyelitis of the tubular bones of the hand. J Hand Surg 1997;22A:644-9.

2 Stevanovic MV, Sharpe F. Acute infections in the hand. In: Green DP, Pederson WC, Hotchkiss RN, Wolfe SW, eds. Green's operative hand surgery. 5th edn. Philadelphia: Elsevier Churchill Livingstone, 2005:55-93.

3 Armstrong P, Wastie M, Rockall A. Bone disease. In: Armstrong P, Wastie ML, Rockwall AG, eds. Diagnostic Imaging. 5th edn. Oxford: Blackwell, 2004:301-33.

4 Lazzarini L, Lipsky BA, Mader JT. Antibiotic treatment of osteomyelitis: what have we learned from 30 years of clinical trials? Int I Infect Dis 2005;9:127-38.

Copyright 2013 BMJ Publishing Group. All rights reserved. For permission to reuse any of this content visit http://group.bmj.com/group/rights-licensing/permissions.

BMJ Case Report Fellows may re-use this article for personal use and teaching without any further permission.

Become a Fellow of BMJ Case Reports today and you can:

- Submit as many cases as you like

- Enjoy fast sympathetic peer review and rapid publication of accepted articles

- Access all the published articles

- Re-use any of the published material for personal use and teaching without further permission

For information on Institutional Fellowships contact consortiasales@bmjgroup.com

Visit casereports.bmj.com for more articles like this and to become a Fellow 